\title{
The Impact of Digital Literation and Infrastructure Facilities of the Output of Teachers in SMK Negeri Prabumulih City
}

\author{
Irfina $^{1 *}$, Happy Fitria $^{2}$, Rohana $^{2}$
}

\author{
${ }^{1}$ SMA Negeri Prabumulih \\ ${ }^{2}$ Universitas PGRI Palembang \\ *Corresponding author. Email: irfinamp3@gimail.com
}

\begin{abstract}
Teacher performance is an important aspect of the effort to achieve learning goals. On the basis of various previous studies, schools with good performance teachers will have a better quality of education. Teacher performance, influenced by a variety of factors. Among other things: teacher competence, motivation and compensation. In addition, the infrastructure that promotes the implementation of teachers' duties. This quantitative research discusses the issue of the impact of digital literacy and infrastructure on the performance of Prabumulih City state vocational School teachers. The research subjects were teachers at Prabumulih city State vocational school. Data triangulation was carried out by means of questionnaires as well as observation and documentation studies. The results showed that there was a significant impact of digital literacy and infrastructure on the performance of Prabumulih city state vocational school teachers.
\end{abstract}

Keywords: Digital Literation, Infrastructure, Performance of Teachers

\section{INTRODUCTION}

Today, the most important issue in the world of Indonesian education is the low quality of education. Education is the most significant predictor for the growth of a nation [1]. Modern education bears the fate of responsibility for negative trends in the moral and spiritual sphere of mankind [2]. The low quality of education can be seen from the low level of achievement of Indonesian junior high school students at the PISA event. In recent years, the triennial publication of the PISA (Program for International Student Assessment) has always provided a sad picture of the low level of proficiency of Indonesian students. At secondary school level, particularly SMK, the low quality of education is the reason why many SMK graduates are unemployed. The high quality of education is much influenced by the quality of the learning process undertaken by teachers [3].

Teachers must have at least four types of competencies in this regard. Professional competence is one of them. One of the indicators of this competence is currently the mastery of digital literacy by teachers. Digital literacy is a very urgent need for teachers to master. Khasanah and Herina [4] as saying that digital literacy is a combination of computer literacy and information literacy.
The performance of a teacher cannot be separated from the impact of the existing infrastructure. Professional teachers are the main keys to smooth and successful learning [5]. Regardless of the teacher's ability to master science and technology, without the support of an adequate infrastructure, the expected results cannot be achieved at the most. Learning media and other teaching tools are used as an effort to eliminate verbalism in teaching and learning situations in order to achieve the objectives of teaching itself.

The need for teachers' digital literacy skills is increasingly felt during the Covid 19 pandemic, as it is today. When learning needs to take place online and remotely, the teacher's digital literacy level greatly determines whether the current learning model can work as well as possible. In addition, the need for adequate infrastructure must be a concern.

Teachers are a resource in schools that plays a very important role in improving the quality of students. Suitable teaching also could make significant graduates [6]. The teacher is responsible for guiding and guiding student learning in order to achieve maximum results. Educational institutions must therefore pay particular attention to improving the performance of teachers. With an increase in teacher performance, quality education outcomes can be achieved in the future of the nation and 
the state. The progress of a nation lies in the country's ability to create quality education for every citizen to achieve its goals.

According to the above description, this study will discuss the impact of digital literacy and infrastructure on the performance of state vocational school teachers in Prabumulih City.

The wording of the hypothesis in this study is as follows: (1) Digital literacy has a significant impact on the performance of teachers. (2) There is a significant impact of the infrastructure on the performance of teachers. (3) The impact of digital literacy and infrastructure on the performance of teachers at state vocational high schools in Prabumulih City is significant.

\section{METHODS}

This method of the research is a quantitative study of state vocational high schools in Prabumulih. To be held from September to December 2020. Methods is a decisive factor throughout the value of the writing of scientific papers [7];[10].

The population of this study consisted of 150 teachers using the Slovin formula. The sample was 109 teachers from 2 schools. The data collection tools used

were questionnaires, observation and documentation studies. The validity and reliability test of the questionnaire was conducted by 20 respondents in order to obtain valid and reliable questionnaire items as a data collection tool in this study.

The rating scale used for this study is the Likert scale. In this questionnaire, the researcher eliminates alternative answers because the questionable answers lead to the tendency of the respondents to choose alternative answers. There are two types of statements used in this questionnaire, namely positive and negative statements.

The data analysis technique used in this study simple correlation and multiple regression data analysis techniques with the help of statistical data processing software. The implementation phase of the analysis includes: (1) Descriptive Analysis, (2) Analysis Requirements Test, and (3) Hypothesis Testing [8]. The research approach has a particular design for research. This research approach is quantitative research by explaining the results of the research [9].

\section{RESULTS AND DISCUSSION}

Table 1. Teacher Performance Percentage Category

\begin{tabular}{ccccc}
\hline No & Range & Freq & $\%$ & Category \\
\hline 1 & $\geq 80$ & 39 & 48,75 & Very Good \\
2 & $76 \mathrm{~s} / \mathrm{d}<80$ & 5 & 6,25 & Good \\
3 & $72 \mathrm{~s} / \mathrm{d}>76$ & 21 & 26,25 & Sufficient \\
4 & $68 \mathrm{~s} / \mathrm{d}<72$ & 15 & 18,75 & Deficient \\
5 & $<68$ & 0 & 0 & Very Deficient \\
\hline
\end{tabular}

From the table above, the data category for the very good standard range is the largest, namely $48,75 \%$ or 39 out of 80 respondents. Whereas the second order is a sufficient category chosen by 21 respondents $(26.25 \%)$.
When it comes to the mean (mean value) of the questionnaire, which is 77.2125 , it can be said that the average choice of respondents is in the right category.

Table 2. Teachers' Digital Literacy Percentage Category

\begin{tabular}{ccccc}
\hline No & Range & Frequence & $\%$ & Category \\
\hline 1 & $\geq 89$ & 0 & 0,0 & Very good \\
2 & $83 \mathrm{~s} / \mathrm{d}<89$ & 36 & 45,00 & Good \\
3 & $77 \mathrm{~s} / \mathrm{d}>83$ & 29 & 36,25 & Enough \\
4 & $71 \mathrm{~s} / \mathrm{d}<77$ & 15 & 18,75 & Less \\
5 & $<71$ & 0 & 0 & Very less \\
\hline
\end{tabular}

From the table above, the data category for a good standard range is the largest, namely 45.00 per cent or 36 out of 80 respondents. Whereas the second order is a sufficient category chosen by 29 respondents (36.25\%). The lesser category was chosen by 15 respondents
$(18.75 \%)$. For the lowest and highest categories, $0 \%$ is chosen or not by the respondents. If it relates to the mean value in the teacher's digital literacy questionnaire, which is 81,5125 , the average respondent will choose the appropriate category. 
Table 3. Category Percentage of Infrastructure

\begin{tabular}{ccccc}
\hline No & Range & Frequence & $\%$ & Category \\
\hline 1 & $\geq 75$ & 0 & 0,0 & Very good \\
2 & $70 \mathrm{~s} / \mathrm{d}<75$ & 26 & 32,50 & Good \\
3 & $65 \mathrm{~s} / \mathrm{d}>70$ & 29 & 36,25 & Enough \\
4 & $60 \mathrm{~s} / \mathrm{d}<65$ & 25 & 31,25 & Less \\
5 & $<60$ & 0 & 0 & Very less \\
\hline
\end{tabular}

From the table above, the data category for a sufficient standard range is the largest, namely $36.25 \%$ or 29 out of 80 respondents. The range of standards chosen by the respondents is not too different for both good and lesser categories. If it relates to the average value of
67.1000 on the infrastructure questionnaire, the respondents chose a sufficient category on average.

The results of multiple regression tests are shown in the table below:

Table 4. Multiple Regression

Coefficients ${ }^{\mathrm{a}}$

\begin{tabular}{|c|c|c|c|c|c|}
\hline \multirow[b]{2}{*}{ Model } & \multicolumn{2}{|c|}{$\begin{array}{c}\text { Unstandardized } \\
\text { Coefficients }\end{array}$} & \multirow{2}{*}{$\begin{array}{r}\text { Standardized } \\
\text { Coefficients }\end{array}$} & \multirow[b]{2}{*}{$\mathrm{t}$} & \multirow[b]{2}{*}{ Sig. } \\
\hline & $\mathrm{B}$ & Std. Error & & & \\
\hline \multirow{3}{*}{$\begin{array}{ll}1 & \text { (Constant) } \\
& \text { Digital Literation } \\
& \text { Infratructur Facilities }\end{array}$} & 8,088 & 11,290 & & 6,277 & ,000 \\
\hline & ,489 & -019 & ,532 & 5,311 & , 000 \\
\hline & ,406 & 825 & ,460 & 4,593 & ,000 \\
\hline
\end{tabular}

Based on the results of the multiple regression test described above, the regression equation constant value (a) is 11,290 and the coefficient value of the independent variable (b1) is- 0,019 and the value (b2) is 0,825 , the regression equation is obtained as follows.

$$
\begin{aligned}
& Y=a+b 1 X_{1}+b 2 X_{2} \\
& Y=11.290-0,019 X_{1}+0.825 . X_{2}
\end{aligned}
$$

This means that through digital literacy and infrastructure, performance has increased positively. In order to find out the truth of the hypothesis tests, a simultaneous test was carried out using the $\mathrm{F}$ test to determine the effect of zoning system variables and school culture on the variable quality of education. The test criteria are as follows:

a. If the probability value (significant) is $<0.005$, then $\mathrm{H}_{03}$ is rejected.

b. If the probability value (significant) is $>0.005$, then $\mathrm{H}_{03}$ is accepted. Then, for the $\mathrm{F}$ test, the test criteria are as follows.

$$
\begin{aligned}
& \mathrm{H}_{\mathrm{a} 4} \text { accepted if } \mathrm{F}_{\text {count }}>\mathrm{F}_{\text {table }} \\
& \mathrm{H}_{04} \text { rejected if } \mathrm{F}_{\text {count }} \leq \mathrm{F}_{\text {ttable }}
\end{aligned}
$$

The research hypothesis is the following:

Ha3: There is a significant impact on the performance of teachers at state vocational high schools in Prabumulih City between teacher digital literacy and infrastructure.
Ho3: There is no significant effect jointly between teacher digital literacy and infrastructure on teacher performance at state vocational hig school in Prabumulih city.

\section{CONCLUSION}

There is a significant influence on the performance of teachers at the Prabumulih City Vocational School between the digital literacy of teachers. In other words, in general, the performance of teachers will increase along with an increase in teacher literacy skills. There is a significant influence between infrastructure and performance of teachers at state vocational high schools in the city of Prabumulih. Good infrastructure will support the performance of teachers. There is a significant influence jointly between teacher digital literacy and infrastructure on teacher performance at state vocational high schools in Prabumulih city.

\section{ACKNOWLEDGMENTS}

The author would like to say thank you to Dr.H. Bukman Lian, M.M., M.Si., Chancellor of PGRI Palembang University, Dr. Syaiful Eddy, M.Sc., Director of the Postgraduate Program at PGRI Palembang University, Dr. Happy Fitria, M.Pd., Head of Education Management Study Program and all those who have contributed both materially and morally. May all this become multiple good deeds. 


\section{REFERENCES}

[1] Asvio, N., Yamin, M., \& Risnita. (2019). Influence of Leadership Style, Emotional Intelligence and Job Satisfaction toward Organizational Commitment (Survey at SMA Muhammadiyah South Sumatera). International Journal of Scientific \& Technology Research 8 (8).

[2] Maseleno, A., Ayshwary, B., Ivanova, T. N., Hashim, W., Nguyen, P. T., Shankar, K., Kristiawan, M., Huda, M. (2019). General Theoretical and Philosophical Aspects of Modern Education. Aspectos Teóricos y Filosóficos Generales de la Educación Moderna. Revista San Gregorio 2019, No. 32 Special Issues August.

[3] Murtiningsih, Kristiawan, M., \& Lian, B. (2019). The Correlation Between Supervision of Headmaster and Interpersonal Communication with Work Ethos of The Teacher. European Jurnal of Education Studies 6(1). Retrieved from http://dx.doi.org/10.46827/ejes.v0i0.2398

[4] Khasanah, U., \& Herina, H. (2019). Membangun Karakter Peserta didik Melalui Literasi Digital dalam Menghadapi Pendidikan Abad 21 (Revolusi Industri 4.0) [Building Student Character Through Digital Literacy in Facing 21st Century Education (Industrial Revolution 4.0)]. Prosiding Seminar Nasional Program Pascasarjana Universitas PGRI Palembang, hal. 1001-1015.

[5] Salwa., Kristiawan, M., \& Lian, B. (2019). The Effect of Academic Qualification, Work Experience and Work Motivation towards Primary School Principal Performance. International Journal of Scientific \& Technology Research, 8(8).

[6] Hanim, H., \& Rahmadoni, J. (2020). Determination of Lecturer Reception Using Analytical Hierarchy Process (AHP). Journal of Applied Engineering and Technological Science (JAETS), 1 (2), 136-141.

[7] Muttaqin, K., \& Rahmadoni, J. (2020). Analysis And Design of File Security System AES (Advanced Encryption Standard) Cryptography Based. Journal of Applied Engineering and Technological Science (JAETS), 11(2), 113-123. https://doi.org/10.37385/jaets.v1i2.78

[8] Sugiyono. (2018). Metode Penelitian Kuantitatif [Quantitative Research Methods]. Bandung: Alfabeta.

[9] Sukmadinata, N. S. (2015). Metode Penelitian Pendidikan [Educational Research Methods]. Bandung: Remaja Rosdakarya.

[10] Sugiyono. (2013). Metode Penelitian Kuantitatif dan $R$ dan $D$ [Quantitative Research Methods and R and D]. Bandung: Alfabeta. 